\title{
RELATIONSHIP BETWEEN CONFORMITY AND CONSUMPTIVE BEHAVIOR IN FEMALE ADOLESCENTS
}

\author{
Aghesna Fadhila Rahmatika ${ }^{1 *}$; Rosita Endang Kusmaryani² \\ 1,2 Postgraduate of Psychology, Universitas Negeri Yogyakarta \\ Jl. Colombo Yogyakarta No. 1, Sleman, Daerah Istimewa Yogyakarta 55281, Indonesia \\ 'aghesnafadhila.2018@student.uny.ac.id; 2rosita_ek@uny.ac.id
}

Received: $10^{\text {th }}$ July 2020/ Revised: 27 July 2020/ Accepted: 24 $4^{\text {th }}$ August 2020

How to Cite: Rahmatika, A. F., \& Kusmaryani, R. E. (2020). Relationship between conformity and consumptive behavior in female adolescents. Humaniora, 11(3), 177-182. https://doi.org/10.21512/humaniora.v11i3.6567

\begin{abstract}
The research aimed to investigate the relationship between conformity and consumptive behavior in female adolescents. It applied a quantitative method with ex-post facto design. The sample was 97 female adolescents in Yogyakarta and was determined using a convenience sampling technique. They completed two questionnaires of conformity and consumptive behavior. The instrument validation technique used content validity, and the validity of the instruments was measured by psychology measurement experts. The instruments' reliability was analyzed using Cronbach Alpha with coefficients of 0,914 (consumptive behavior) and 0,790 (conformity). Data analysis techniques used Pearson product-moment correlation analysis. The result of the research shows that there is a significant positive relationship between conformity and consumptive behavior in female adolescents. In other words, conformity can be a strong predictor of consumptive behavior in female adolescents.
\end{abstract}

Keywords: female conformity, consumptive behavior, female adolescent

\section{INTRODUCTION}

The rapid development of technology in today's society makes people's lifestyles also increasingly developing in everyday life. This makes a person become unrealistic in thinking and making decisions to consume something to follow that lifestyle. Nowadays, society develops daily, where people use the internet to carry out all types of transactions from transportation, buying food, and shopping for goods for their daily needs. This forms a new lifestyle supported by the ease of getting information and goods desired only by using digital media (social media, shopping platforms, and online transportation) that quickly affect each user. Everyone has a variety of ways to meet their needs. However, it is anxious if the individual cannot control their lifestyle that will lead to a consumptive lifestyle (Mulyani, Thomas, \& Widiyanto, 2018).

In everyday life, society cannot be separated from consumptive behavior. In this modern era, consumptive behavior grows rapidly among people. Individuals tend to buy a product more than what they really need. It occurs because humans have many desires (Enrico, Aron, \& Oktavia, 2014). Consumptive behavior should be avoided so as not to take root in a person and become a lifestyle so that they can consider the needs and desires (Suparti, 2016).

Consumptive behavior is defined as a human tendency to consume unlimited consumption, where they are more concerned with wants than needs (Mowen \& Minor, 2002). According to Lina and Rosyid (1997), the aspects of consumptive behavior are impulsive buying, wasteful buying, and nonrational buying. The impulsive buying aspect shows that the individual makes a purchase based solely on an individual's impulse without considering it first and thinking about what will happen later. The wasteful buying aspect shows that individuals make excessive purchases without being based on exact needs. Nonrational buying aspects are purchases that are made not out of necessity, but because of the prestige to be impressed as modern or fashionable.

Among those who have consumptive behavior in this modern era is someone who enters adolescence to adulthood (Anwar, Lusiana, \& Rahman, 2019). 
Steinberg (2015) has defined adolescence as a stage of life when someone is not yet an adult. Adolescents face many challenges in their development process due to changes in their biological, cognitive, and social-emotional (Santrock, 2014). Biological changes include changes in the physical, cognitive changes include changes in the way of thinking, while socialemotional changes include changes in the relationship between individuals and others. Late adolescents often do consumptive behavior by repeatedly and excessively (Ardyanti \& Kardoyo, 2018; Enjaian, Zeigler-Hill, \& Vonk, 2017; Pradipto et al., 2016; Rizkallah \& Truong, 2010; Sari, 2016). Adolescents tend to prioritize appearance to look attractive and trendy because, basically, they look more at fashion than needs. Likewise, what happens to female students who are part of the late teens. Consumptive behavior in female students can occur if they see the female age as a transitional age in seeking self-identity.

Consumptive behavior is a behavior of buying and using goods that are not based on rational considerations and have a tendency to consume an unlimited amount where the individual is more concerned with fulfilling wants rather than needs. The characteristics of people who behave consumptively are someone buying something because the seller offering a prize, buying because the packaging is attractive, buying because of maintaining self-appearance and prestige, buying because of a discounted price program, buying because of the influence of models that advertise goods, buying because to increase selfconfidence, buy more than two of the same item with different brands (Fardhani \& Izzati, 2013).

The available literature shows that late adolescents' consumptive behavior is influenced by social and personal factors (Kotler \& Keller, 2016). Schiffman, Kanuk, \& Hansen (2012) have said that individuals who tend to do consumptive behavior are not only influenced by family, friends, and advertisements, but also influenced by moods, situations, and emotions. One of the social factors that influence consumptive behavior is the reference group of peers (Fitriyani, Widodo, \& Fauziah, 2013; Haryani \& Herwanto, 2015; Yuliantari \& Herdiyanto, 2015). One of the most powerful mechanisms through peer influence is conformity (Gommans et al., 2017; Kotler \& Keller, 2016).

One of the causes of consumptive behavior that occurs in adolescents is social factors. There are reference groups that directly or indirectly influence individual attitudes and behavior, including adolescent consumptive behavior. Conformity arises when individuals imitate others' attitudes and behavior due to real or imagined pressure (Santrock, 2014). It is feared that adolescents accustomed to consumptive behavior will continue to undergo the same behavior patterns until they are in the workforce. If there is no match between income and desire, then there is a tendency to commit corruption. For adolescents who come from families with high economic stratification can impact the formation of compulsive shopping behavior (Suminar \& Meiyuntari, 2015).

Baron and Byrne (2004) have said that conformity is a type of social influence in which individuals change their attitudes and behavior to match existing social norms. Conformity that occurs in adolescents arises from the result of a desire to be accepted by friends. Conformity is the act of adjusting to the group. As creatures that live in groups, most of our behavior is focused on maintaining relationships with groups (Coultas \& Van Leeuwen, 2015; Wijenayake et al., 2020). According to Myers (2015), conformity is a change in behavior or action caused by pressure from a group. Individuals can be affected through an unconscious process or directly through peer pressure. Individuals often do conformity to get a sense of security. Most people behave according to social norms by showing a strong tendency to conform. These social norms tend to influence a person's behavior if it is relevant to him/her. Overall, individuals feel far more comfortable when doing or having something in common with friends or family than when they are different.

According to Chaplin (2011), conformity tends to allow a person's behavior to be controlled by attitudes and opinions that already apply. Furthermore, Chaplin (2011) has explained conformity as a trait that carries a personality that tends to allow the attitudes and opinions of others to dominate his/her life. Conformity is a change in behavior or action caused by pressure from a group. Under intense social pressure, individuals will adjust to the group even to do something immoral (Aronson et al., 2016). Asch's study shows that when an individual discovers information from a group that contradicts his/her understanding, it is likely that he/ she will revise the response to match what the group has (Beran et al., 2015; Forsyth \& Burnette, 2010). According to Baron and Byrne (2004), the aspects of conformity are normative and informational aspects. The normative aspect is based on the desire to be liked and the fear of rejection, and the informational aspect is based on the desire to feel right.

Peer conformity shows a significant effect on consumptive behavior. Adolescents who have high conformity will tend to behave consumptively (Mahrunnisya, Indriayu, \& Wardani, 2018). Conformity in female adolescents causes them to spend more money to support their appearance by buying the same items with their group of friends, excessively and repeatedly (consumptive behavior). They do this so they can always be accepted as members of the group. Acceptance by peers becomes something that is quite a concern for adolescents. Therefore, to be accepted by peers, adolescents will try to be in line with the group's patterns and expectations to avoid rejection. Taylor, Peplau, and Sears (2009) have stated that if someone performs a certain behavior voluntarily because someone else is also doing it, it is called conformity. Conformity is not just acting in accordance with the actions taken by others, but also means being influenced by how they act.

Previous research has shown that individuals 
who tend to conform are girls (Goldsmith, Clark, \& Lafferty, 2005; Gommans et al., 2017; Le, 2019). In line with the results of the research of Gommans et al. (2017), which states that female adolescents have more conformity compared to male adolescents. This happens because female adolescents have a strong relationship orientation with their groups to maintain harmony and a high desire to be popular. Whether there is real pressure or not, which occurs in groups, causes adolescents to be willing to spend an excessive amount of money to buy things that are not needed. Besides, studies have also shown that individuals who have conformity with friends tend to behave in a consumptive manner (Fitriyani, Widodo, \& Fauziah, 2013; Mahrunnisya, Indriayu, \& Wardani, 2018).

Based on the literature review and previous studies, the aim of the research is to examine the relationship between conformity and consumptive behavior in adolescents. The hypothesis is that there is a significant relationship between conformity and consumptive behavior in female adolescents.

\section{METHODS}

The research applies a quantitative method with ex-post facto research (Cohen, Manion, \& Morrison, 2018). The research is conducted in Yogyakarta. The 97 participants are recruited incidentally with two criteria, namely, female sex and aged around 17-23 years $(\mathrm{M}$ age $=20,56, \mathrm{SD}=2,06)$. Participants are high school students and female students at universities in Yogyakarta. Participation in this research is voluntary. The sampling technique used is convenience sampling. The instrument validity technique used is content validity, whereas to test reliability, the Cronbach Alpha formula is applied. The consumer behavior questionnaire has an Alpha Cronbach value of 0,914 and a conformity questionnaire of 0,790 .

Data collection techniques are using a questionnaire. The research instrument uses a scale consisting of 2 scales; the scale of consumptive behavior (consists of 20 statement items) and the conformity scale (consists of 20 statement items). The consumer behavior scale developed based on the theory of Lina and Rosyid (1997) consists of three aspects, namely impulsive buying, wasteful buying, and non-rational buying. The conformity scale developed based on the theory of Baron and Byrne (2004) consists of two aspects, namely the normative and informational aspects. The analysis technique used is the Pearson Product Moment correlation analysis. The researchers conduct a normality test with the Kolmogorov-Smirnov technique. The hypothesis test is done using the SPSS program.

\section{RESULTS AND DISCUSSIONS}

Table 1 shows descriptive statistics containing the mean, standard deviation, and the total number of subjects $(\mathrm{N})$ for each variable. This shows that the mean value of the conformity variable $(\mathrm{m}=45,30, \mathrm{SD}$ $=10,501)$, and the consumptive behavior variable ( $\mathrm{m}$ $=42,68, \mathrm{SD}=14,257)$. The range of data values of consumptive behavior and conformity is $26-88$ and 28-66.

Table 1 Results of Data Description

\begin{tabular}{lcc}
\hline \multicolumn{1}{c}{ Statistic } & $\begin{array}{c}\text { Consumptive } \\
\text { Behavior }\end{array}$ & Conformity \\
\hline Mean & 42,68 & 45,30 \\
Std. Deviation & 14,257 & 10,501 \\
Minimum & 26 & 28 \\
Maximum & 88 & 66 \\
\hline
\end{tabular}

Table 2 shows the results of the normality test of the variables. It shows the results of a significant value (p) $=0,489$. Then, the normality test results show that the variables of conformity and consumptive behavior have a normal distribution that is $p>0,05$ (a significance value is greater than 0,05 , which is $0,489>0,05)$. In other words, all the variables are normally distributed because the significant value of each variable is $>0,05$.

The results of the analysis through Pearson correlation shows that the hypothesis tested in this research is accepted. The data analysis in Table 3 shows the correlation test obtained a significant value (p) of 0,000 , which means it is smaller than the level of significance value of $0,05(0,000<0,05)$. The correlation coefficient (r) in this research shows that the result is 0,541 , which means the direction of the positive correlation with the interpretation of the correlation is moderate.

Table 2 Normality Test Results

\begin{tabular}{cccc}
\hline & \multicolumn{3}{c}{ Kolmogorov-Smirnov } \\
\cline { 2 - 4 } & Statistic & df & Sig. \\
\hline $\begin{array}{c}\text { Unstandardized } \\
\text { Residual }\end{array}$ & 0,085 & 97 & 0,489 \\
\hline
\end{tabular}

Table 3 Pearson Correlation Test Results

\begin{tabular}{lcc}
\hline \multicolumn{1}{c}{ Model } & $\begin{array}{c}\text { Pearson } \\
\text { Correlation }\end{array}$ & Sig. \\
\hline Conformity & 0,541 & 0,000 \\
Consumptive Behavior & 0,541 & 0,000 \\
\hline
\end{tabular}

Based on the results of the regression test in Table 4 , it is obtained the $r_{\text {square }}$ value of 0,293 . It means that the conformity variable influences consumptive behavior by $29,3 \%$ so that $70,7 \%$ of consumptive behavior is still influenced by other factors. 
Table 4 The Coefficient of Determination

\begin{tabular}{ccccc}
\hline Model & $\mathbf{R}$ & $\begin{array}{c}\text { R } \\
\text { Square }\end{array}$ & $\begin{array}{c}\text { Adjusted } \\
\text { R Square }\end{array}$ & $\begin{array}{c}\text { Std. Error } \\
\text { of the Esti- } \\
\text { mate }\end{array}$ \\
\hline 1 & 0,541 & 0,293 & 0,286 & 12,050 \\
\hline
\end{tabular}

The research results show there is a positive relationship between conformity and consumptive behavior that can be said to be accurate and in accordance with existing theories. The research is in line with the research conducted by Haryani and Herwanto (2015). It has said that shopping becomes an outlet that ultimately makes female adolescents become a consumptive generation. Another research conducted by Fardhani and Izzati (2013) has stated that conformity is significantly a predictor of adolescents' consumptive behavior. Conformity is an external factor that can influence a person to engage in consumptive behavior. This positive result occurs because, in the research, the higher the level of conformity a person does, the higher the intensity of someone to behave consumptively. This is because the social influence obtained from the reference group is considered credible, interesting, and strong so that it can encourage, influence one's beliefs, attitudes, and behavior to engage in consumptive behavior (Schiffman, Kanuk, \& Hansen, 2012).

Conformity means that individuals change their attitudes or behavior to suit others because of social pressure (Gommans et al., 2017). Often what motivates conformity in adolescents is the urge to get social approval and acceptance from the peer group. One of them is adjusting to the majority's attitudes or behaviors; when the group has new goods that cause them to buy things like their friends in the group. Another motive to conform is known as the informational influence. When adolescents are confused about the right response, they tend to seek guidance (social) through their friends. Therefore, it can be concluded that the negative impact given by conformity will increase the occurrence of consumptive behavior. The results of the research support the results of Yuliantari and Herdiyanto 'research (2015). It shows that individuals who tend to conform to peers will have a tendency to behave consumptively.

Conformity can occur if a group has many members. In addition, a group's social status can be a powerful influence for a person to conform. Individuals will also tend to feel safe and comfortable to voice the same opinion as a group. They do this to be accepted in the group and strengthen attachment to the group (Baron \& Branscombe, 2012). According to Baron and Byrne (2004), there are two aspects of conformity; normative and informational. The normative aspect includes changing attitudes or behavior to meet others' expectations, get the coveted acceptance, and avoid rejection. Since childhood, humans have been embedded that doing what others like will get the desired approval and acceptance. Suppose the tendency to conform to social norms is rooted in the desire to be liked and accepted by others. In that case, anything that can increase the fear of rejection by others will also increase conformity.

The informational aspect is based on the desire to feel right. Motivation to feel right and accurate encourages individuals to refer to others. Opinions and actions of others are used as guidelines for opinions and actions that an individual takes when in ambiguous situations. When individuals feel unsure about what is appropriate in a particular situation, they will refer to others with the aim of finding that accuracy. In other words, individuals tend to depend on others as a source of information about various aspects of the social world.

One of the factors influencing one's consumptive level is the reference group (Kotler \& Armstrong, 2018). What is meant by reference groups, in this case, is friendship groups. Individuals in adolescence tend to do conformity by forming attitudes and behavior in accordance with the group of friends as a reference. The extent to which the reference group affects a person's behavior depends on the extent to which the individual is affected by the reference group and the strength of its involvement in the group (Pride \& Ferrel, 1995).

Basically, high school students and college students are educational levels that have a high level of conformity compared to other levels of education in Yogyakarta. This opinion is based on the study of Santrock (2014), which states that high school and university students have begun to develop a more independent decision style from the influence of peers and parents. Besides, they are faced with a new world that is different from the middle school and requires them to adapt to the environment. When the adaptation process takes place, they tend to adjust their opinions, attitudes, actions, and perceptions according to their peers' opinions, attitudes, actions, and perceptions, thereby stimulating their conformity behavior.

The relationship between conformity and consumptive behavior that occurs in adolescents in Yogyakarta has a medium category. The research's results are consistent with research by Carter et al. (2019), which states that consumptive behavior is influenced by conformity. Individuals are more likely to adjust to the norms set by their groups to avoid prejudice and rejection. Conformity can predict impulsive buying in adolescents. Peer conformity for adolescents has an influence in terms of buying behavior. This seems inseparable from adolescents' desire to look attractive, not unlike their peers, and to be accepted as part of a group. As a result, adolescents are encouraged to behave consumptively because adolescents want their appearance to be the same as peers and accepted as a group.

Adolescents have many desires in life. From an early age, many children are taught to obey norms to be accepted by the community where they live. This is the same as when an adolescent begins to 
prefer to hang out with his/her peers. They will do and buy things that his/her friends like because they want to be accepted. This can trigger individuals to make impulsive purchases. Therefore, it is important for adolescents to control their desire to conform to friends so that individuals' consumptive behavior can be minimized.

The effective contribution produced in the research is $29,3 \%$, which means that the level of conformity only contributes $29,3 \%$ to adolescents' consumptive behavior. This figure indicates that other factors are also associated with consumptive behavior in adolescents that are not observed in this research. It is because of research limitations, such as personality factors, attitudes, and buying motivation that affect adolescents in shopping. Associated with these explanations, especially young women, to prevent consumptive behavior, they should prioritize their needs rather than just desires. This is done so that adolescents are not trapped in consumptive behavior and can prevent the occurrence of negative effects from high consumptive behavior, such as behavior that justifies any means to get the desired item, for example by stealing, or other criminal acts.

\section{CONCLUSIONS}

The research shows that conformity is the predictor of consumptive behavior in adolescents. The higher level of conformity is, the higher consumptive behavior in adolescents will be, and vice versa. The limitation of the research is in the respondents. There are only a few respondents; thus, the findings cannot be generalized to all adolescents. However, it still contributes theoretically to the existing literature. The results of the research propose several recommendations for future researchers. First, other variables should be analyzed, such as self-esteem, self-control, and lifestyle. Second, future researchers should use different approaches like the qualitative method and use the different respondents to address this issue.

\section{REFERENCES}

Anwar, R. K., Lusiana, E., \& Rahman, M. T. (2019). Internet advertising and consumptive. Temali: Jurnal Pembangunan Sosial, 2(1), 46-60.

Ardyanti, N., \& Kardoyo. (2018). Determinants of consumption behavior among students. Dinamika Pendidikan, 13(1), 30-41. https://doi.org/10.15294/ dp.v13i1.15112.

Aronson, E., Wilson, T. D., Akert, R. M., \& Sommers, S. R. (2016). Social psychology (9 ${ }^{\text {th }}$ Ed.). New York: Pearson Education.

Baron, R.A., \& Branscombe, N. R. (2012). Social psychology $\left(13^{\text {th }}\right.$ Ed.). New Jersey: Pearson Education.Inc.

Baron, R. A., \& Byrne, D. (2004). Psikologi sosial. Jakarta: Erlangga.
Beran, T., Drefs, M., Kaba, A., Al Baz, N., \& Al Harbi, N. (2015). Conformity of responses among graduate students in an online environment. The Internet and Higher Education, 25, 63-69. https://doi. org/10.1016/j.iheduc.2015.01.001.

Carter, M. F., Franz, T. M., Gruschow, J. L., \& Vanryne, A. M. (2019). The gender conformity conundrum: The effects of irrelevant gender norms on public conformity. The Journal of Social Psychology, 159(6), 761-765. https://doi.org/10.1080/00224545 .2019 .1586636 .

Chaplin, J. P. (2011). Kamus lengkap psikologi. Jakarta: Raja Grafindo Persada.

Cohen, L., Manion, L., \& Morrison, K. (2018). Research methods in education ( $8^{\text {th }} \mathrm{Ed}$.). New York: Routledge.

Coultas, J. C., \& Van Leeuwen, E. J. C. . (2015). Conformity: Definitions, types, and evolutionary grounding. In V. Zeigler-Hill, L. Welling, \& T. Shackelford (eds), Evolutionary Perspectives on Social Psychology (pp. 189-202). New York: Springer. http://doiorg-443.webvpn.fjmu.edu.cn/10.1007/978-3-31912697-5_15.

Enjaian, B., Zeigler-Hill, V., \& Vonk, J. (2017). The relationship between approval-based contingent self-esteem and conformity is influenced by sex and task difficulty. Personality and Individual Differences, 115, 58-64. https://doi.org/10.1016/j. paid.2016.06.040.

Enrico, A., Aron, R., \& Oktavia, W. (2014). The factors that influenced consumptive behavior: A survey of university students in Jakarta. International Journal of Scientific and Research Publications, 4(1), 1-6.

Fardhani, P. R., \& Izzati, U. A. (2013). Hubungan antara konformitas dan perilaku konsumtif pada remaja (Studi pada siswa kelas XI SMA Trimurti Surabaya). Character: Jurnal Penelitian Psikologi, 1(2), 1-8.

Fitriyani, N., Widodo, P. B., \& Fauziah, N. (2013). Hubungan antara konformitas dengan perilaku konsumtif pada mahasiswa di Genuk Indah Semarang. Jurnal Psikologi Undip, 12(1), 55-68. https://doi.org/10.14710/jpu.12.1.1-14.

Forsyth, D. R., \& Burnette, J. (2010). Group processes. In R. F. Baumeister \& E. J. Finkel (Eds.), Advanced Social Psychology: The State of the Science (pp. 495-534). Oxford: Oxford University Press.

Goldsmith, R. E., Clark, R. A., \& Lafferty, B. A. (2005). Tendency to conform: A new measure and its relationship to psychological reactance. Psychological Reports, 96, 591-594. https://doi. org/10.2466/pr0.96.3.591-594.

Gommans, R., Sandstrom, M. J., Stevens, G. W. J. M., ter Bogt, T. F. M., \& Cillessen, A. H. N. (2017). Popularity, likeability, and peer conformity: Four field experiments. Journal of Experimental Social Psychology, 73, 279-289. https://doi.org/10.1016/j. jesp.2017.10.001.

Haryani, I., \& Herwanto, J. (2015). Hubungan konformitas dan kontrol diri dengan perilaku konsumtif terhadap produk kosmetik pada mahasiswi. Jurnal Psikologi, 11(1), 5-11. http://dx.doi.org/10.24014/jp.v11i1.155.

Kotler, P., \& Armstrong, G. (2018). Principles of marketing 
(L. Albelli, Ed.) (17 $17^{\text {th }}$ Ed.). Harlow: Pearson Education Limited.

Kotler, P., \& Keller, K. L. (2016). Marketing management. In Soldering \& Surface Mount Technology $\left(15^{\text {th }}\right.$ Ed., Vol. 13). New Jersey: Pearson Education. https:// doi.org/10.1108/ssmt.2001.21913cab.040.

Le, T. P. (2019). The association of conformity to feminine norms with women's food consumption after a negative mood induction. Appetite, 133, 123-129. https://doi.org/10.1016/j.appet.2018.10.031.

Lina., \& Rosyid, H. F. (1997). Perilaku konsumtif berdasar locus of control pada remaja putri. Psikologika: Jurnal Pemikiran dan Penelitian Psikologi, 2(4), 5-13. https://doi.org/10.20885/psikologika.vol2. iss4.art1.

Mahrunnisya, D., Indriayu, M., \& Wardani, D. K. (2018). Peer conformity through money attitudes toward adolescence's consumptive behavior. International Journal of Multicultural and Multireligious Understanding, 5(4), 30-37. https://doi. org/10.18415/ijmmu.v5i4.163

Mowen, J. C., \& Minor, M. (2002). Perilaku konsumen. Jakarta: Erlangga.

Mulyani, R., Thomas, P., \& Widiyanto. (2018). The influence of student consumption, social status of family, the economic parent status, and the economic education of family to consumption behavior. Journal of Economic Education, 7(1), 24-30. https:// doi.org/10.15294/jeec.v7i1.22190.

Myers, D. G. (2015). Exploring social psychology ( $7^{\text {th }}$ Ed.). New York: McGraw Hill. https://doi. org/10.2307/1319387.

Pradipto, Y. D., Winata, C., Murti, K., \& Azizah, A. (2016). Think again before you buy: The relationship between self- regulation and impulsive buying behaviors among Jakarta young adults. Procedia - Social and Behavioral Sciences, 222, 177-185. https://doi.org/10.1016/j.sbspro.2016.05.209.

Pride, W. M., \& Ferrel, O. C. (1995). Pemasaran: Teori dan praktek sehari-hari. Jakarta: Bina Rupa Aksara.
Rizkallah, E. G., \& Truong, A. (2010). Consumptive behavior, promotional preferences, and shopping patterns of Hispanic Americans: An empirical perspective. Journal of Business \& Economics Research, 8(4), 111-122. https://doi.org/10.19030/ jber.v8i4.710.

Santrock, J. W. (2014). Adolescence (15 th Ed.). New York: McGraw Hill.

Sari, R. K. (2016). Kecenderungan perilaku compulsive buying (pembelian kompulsif) pada masa remaja akhir di Samarinda. E-journal Psikologi, 4(4), 361372.

Schiffman, L. G., Kanuk, L. L., \& Hansen, H. (2012). Consumer behavior (2 ${ }^{\text {nd }}$ Ed.). Harlow: Pearson Education Limited.

Steinberg, L. (2015). Age of opportunity: Lessons from the new science of adolescence. New York: Houghton Mifflin Harcourt.

Suminar, E., \& Meiyuntari, T. (2015). Konsep diri, konformitas dan perilaku konsumtif pada remaja. Persona: Jurnal Psikologi Indonesia, 4(2), 145-152. https://doi.org/10.30996/persona.v4i02.556.

Suparti, S. (2016). Mitigating consumptive behavior: The analysis of learning experiences of housewives. International Education Studies, 9(3), 114-122. https://doi.org/10.5539/ies.v9n3p114.

Taylor, S. E., Peplau, L. A., \& Sears, D. O. (2009). Social psychology. New Jersey: Pearson Education.

Wijenayake, S., Berkel, N. Van, Kostakos, V., \& Goncalves, J. (2020). Impact of contextual and personal determinants on online social conformity. Computers in Human Behavior, 108, 106302-106302. https:// doi.org/10.1016/j.chb.2020.106302.

Yuliantari, M. I., \& Herdiyanto, Y. K. (2015). Hubungan konformitas dan harga diri dengan perilaku konsumtif pada remaja putri di kota Denpasar. Jurnal Psikologi Udayana, 2(1), 89-99. https://doi. org/10.24843/JPU.2015.v02.101.p09. 